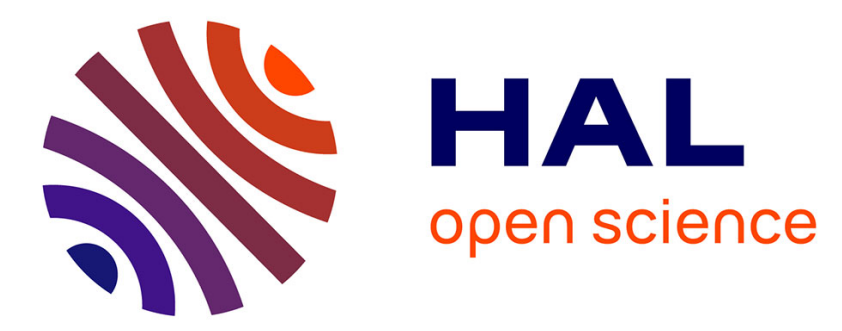

\title{
Changes in amphipod (Crustacea) assemblages associated with shallow-water algal habitats invaded by var. in the western Mediterranean Sea
}

\author{
M. Vazquez-Luis, P. Sanchez-Jerez, J. Bayle-Sempere
}

\section{- To cite this version:}

M. Vazquez-Luis, P. Sanchez-Jerez, J. Bayle-Sempere. Changes in amphipod (Crustacea) assemblages associated with shallow-water algal habitats invaded by var. in the western Mediterranean Sea. Marine Environmental Research, 2008, 65 (5), pp.416. 10.1016/j.marenvres.2008.01.006 . hal-00501938

\section{HAL Id: hal-00501938 \\ https://hal.science/hal-00501938}

Submitted on 13 Jul 2010

HAL is a multi-disciplinary open access archive for the deposit and dissemination of scientific research documents, whether they are published or not. The documents may come from teaching and research institutions in France or abroad, or from public or private research centers.
L'archive ouverte pluridisciplinaire $\mathbf{H A L}$, est destinée au dépôt et à la diffusion de documents scientifiques de niveau recherche, publiés ou non, émanant des établissements d'enseignement et de recherche français ou étrangers, des laboratoires publics ou privés. 


\section{Accepted Manuscript}

Changes in amphipod (Crustacea) assemblages associated with shallow-water algal habitats invaded by Caulerpa racemosa var. cylindracea in the western Mediterranean Sea

M. Vazquez-Luis, P. Sanchez-Jerez, J. Bayle-Sempere

PII:

S0141-1136(08)00016-0

DOI: 10.1016/j.marenvres.2008.01.006

Reference: MERE 3168

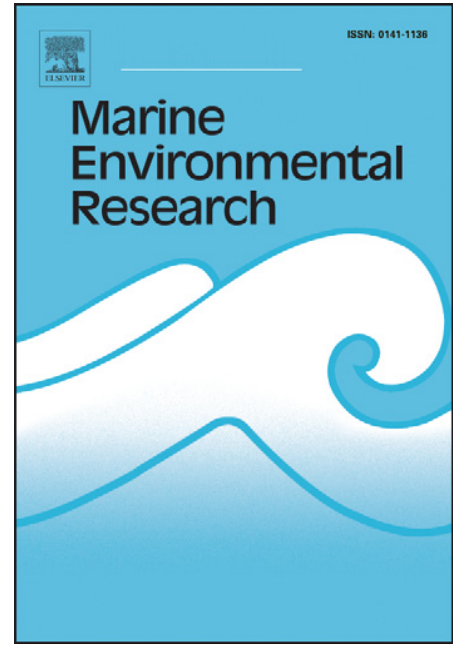

To appear in:

Marine Environmental Research

Received Date:

3 December 2007

Revised Date:

30 January 2008

Accepted Date:

31 January 2008

Please cite this article as: Vazquez-Luis, M., Sanchez-Jerez, P., Bayle-Sempere, J., Changes in amphipod (Crustacea) assemblages associated with shallow-water algal habitats invaded by Caulerpa racemosa var. cylindracea in the western Mediterranean Sea, Marine Environmental Research (2008), doi: 10.1016/j.marenvres.2008.01.006

This is a PDF file of an unedited manuscript that has been accepted for publication. As a service to our customers we are providing this early version of the manuscript. The manuscript will undergo copyediting, typesetting, and review of the resulting proof before it is published in its final form. Please note that during the production process errors may be discovered which could affect the content, and all legal disclaimers that apply to the journal pertain. 
1 Changes in amphipod (Crustacea) assemblages associated with

2 shallow-water algal habitats invaded by Caulerpa racemosa var.

3 cylindracea in the western Mediterranean Sea.

5 Vazquez-Luis ${ }^{1}$, M.; Sanchez-Jerez ${ }^{2}$, P. and Bayle-Sempere, J. ${ }^{2}$

6 (1) Centro de Investigación Marina de Santa Pola (CIMAR), Ayto. de Santa Pola y

7 Univ. de Alicante. Torre d'Enmig s/n, Cabo de Santa Pola, Alicante (Spain).

$8 \quad$ MT.Vazquez@ua.es

9 Tel.: +34 96 5903400x2916

10 Fax: +34965909840

11 (2) Departamento de Ciencias del Mar y Biología Aplicada. Edificio Ciencias V.

12 Universidad de Alicante. POB. 99. E-03080 Alicante (Spain).

14 Abstract

15 The effects of the invasive species Caulerpa racemosa var. cylindracea (hereafter

16 C. racemosa) on amphipod assemblages associated with shallow-water rocky habitats

17 were studied. Two habitats located along the SE Iberian Peninsula were compared;

18 invaded and non-invaded. The results showed that growth of $C$. racemosa affects

19 habitat structure, influencing the species composition and biomass of macroalgae, and

20 detritus accumulation. In turn, such changes in habitat features affected the associated

21 amphipod assemblages with different ecological requirements. However, the species

22 richness of amphipods was relatively high in both habitats, while the species

23 composition of amphipods changed completely. For example, some species such as

24 Ampithoe ramondi and Hyale schmidti did not colonize invaded habitats, while others

25 such as Apocorophium acutum were favoured by the spread of C. racemosa. Habitat 
26 invasion by $C$. racemosa can have an important influence on biotic assemblages,

27 modifying both habitat structure and the associated fauna, with unknown effects on the 28 overall ecosystem.

30 Key words: Amphipoda, Caulerpa racemosa var. cylindracea, detritus, invasive 31 species, Mediterranean Sea, shallow rocky bottoms.

\section{Introduction}

34 The green alga Caulerpa racemosa (Forsskål) J. Agardh var. cylindracea (Sonder)

35 Verlaque, Huisman et Boudouresque (Verlaque et al., 2003) (hereafter C. racemosa) was first detected in Tunisia (Mediterranean Sea) in 1926. More recently, during the 1990s, C. racemosa spread steadily throughout the Mediterranean region (see Piazzi et al., 2005). Recent genetic analyses have shown that the C. racemosa population originated from the southwest coast of Western Australia (Verlaque et al., 2003), and is not a Lessepsian migrant as thought originally. A remarkable spread of C. racemosa

41 throughout the Mediterranean has been recorded during the last 15 years or so, during which the alga invaded different habitats located at water depths of $0 \mathrm{~m}$ to more than 60 $\mathrm{m}$. The recorded rate of invasion has been much faster than that for other invasive 44 species such as Caulerpa taxifolia (Verlaque et al., 2003). The rapid spread of $C$. racemosa can be explained by its very efficient reproductive strategies, both sexual and asexual (via propagules), which is not the case with Caulerpa taxifolia (Panayotidis and

47 Žuljevi`c, 2001; Renoncourt and Meisenez, 2002).

Several studies have demonstrated that habitat heterogeneity and complexity play an important role in influencing the assemblage structure of epibenthic marine fauna (Johnson, 1970; Stoner, 1980; Dean and Connell, 1987; Edgar, 1992; Taylor and Cole, 
51 1994, Ayala and Martín, 2003). The pattern of distribution and species richness and

52 abundance of epifauna on rocky bottoms is affected by changes in the composition of

53 associated macroalgae (Connell, 1972). Therefore, changes in habitat structure of

54 vegetated substrates resulting from the invasion of species such as C. racemosa could

55 affect the associated fauna, including amphipods.

56 Amphipods are one of the most important groups of invertebrates associated with

57 vegetated habitats, and they play an important role as trophic resources for fish

58 populations (Sanchez-Jerez et al., 1999; Stål et al., 2006). Amphipods respond to habitat

59 alteration and can therefore be used as an indicator of environmental impacts on

60 vegetated habitats (Bellan-Santini, 1980; Virnstein, 1987; Conradi et al., 1997;

61 Sanchez-Jerez et al., 2000).

62 Since the first records of spread of C. racemosa along Mediterranean coastal areas,

63 several studies concerning the ecology of this species have been undertaken (see Ruitton

64 et al., 2005; Cavas et al., 2006). However, information on changes on the associated

65 fauna brought about by the invasive alga is lacking (Argyrou et al., 1999; Piazzi and

66 Balata, 2007). The main aim of this study was to assess the effects of C. racemosa on

67 amphipod assemblages associated with a shallow water rocky bottom habitat in the

68 southwestern Mediterranean Sea, by comparing natural rocky algal assemblages and the

69 same habitat type that has been invaded by C. racemosa. The hypothesis tested in our

70 study was: invasion by $C$. racemosa should influence the habitat structure of rocky

71 bottom algal assemblages and, consequently, the assemblage structure of associated

72 epifauna such as amphipods may be affected, in terms of species richness and 73 abundance.

\section{Materials and Methods}




\subsection{Study area}

Fieldwork was carried out along the Cape of Santa Pola (Alicante, south-east Spain; Fig. 1) on a shallow rocky platform. In Alicante, C. racemosa was first recorded in 2002 at a site located around ten kilometres north of our study area, where it colonised soft sediments and dead matte of Posidonia oceanica. Following two months, C. racemosa was detected on the rocky platform in our study area (Pena-Martin et al., 2003). The alien alga now occurs in extensive areas of ecologically important rocky bottoms, on sandy and muddy substrata, and on dead matte of Posidonia oceanica. It also occurs intermixed with Cymodocea nodosa in meadows of the seagrass within a wide depth range $(0.2-1.5 \mathrm{~m})$ and with patchy distribution.

\subsection{Sampling and experimental design}

Shallow rocky habitat, located within the $0.2 \mathrm{~m}-0.5 \mathrm{~m}$ depth range, was sampled. Several sampling sites, separated by hundreds of metres, with C. racemosa and without the alien alga, were randomly selected across the study area. All sites presented similar environmental conditions with respect to wave exposure and light (Ferrandis-Ballester and Bartolomé Pina, 1985). Three 'invaded' rocky habitat sites and another three 'noninvaded' rocky habitat sites were sampled in September 2004 (average water temperature $=27.5^{\circ} \mathrm{C}$ ), which coincides with the period of maximum vegetative growth of the alga (Piazzi and Cinelli, 1999). Other sites were sampled again in March 2005 (water temperature $=13^{\circ} \mathrm{C}$ ) which coincides with the period of minimum vegetative grow. At each site, three random replications were taken using a $20 \times 20 \mathrm{~cm}$ quadrat by scraping the whole surface using a trowel (Edgar, 1990). Samples were separated by tens of meters. A $300 \mu \mathrm{m}$ mesh bag was attached to the quadrat to avoid loss of the motile fauna. Samples were preserved in $4 \%$ solution of formaldehyde in seawater. Each replicate was sieved in sea-water through a $500 \mu \mathrm{m}$ mesh, obtaining the fine 
101 fraction of detritus. In the laboratory, the amphipods were separated, identified, and

102 counted. After that, algae were sorted as well as the bigger fragments of detritus.

103 Afterwards the macrophytes and the detritus were dried for $24 \mathrm{~h}$ at $80{ }^{\circ} \mathrm{C}$, and weighed.

104 The macrophytes were identified to the species level. Habitat structure was

105 characterised using three attributes: species richness of macrophytes, biomass of each

106 species (g) and quantity of detritus (g).

107

108

109 2.3. Data analysis

110 Two different statistical approaches were used to identify potential changes in the

111 amphipod assemblages and habitat features, based on the null hypothesis of no change

112 in amphipod assemblage composition between the two habitat types across different

113 sampling times.

114

$115 \quad$ 2.3.1. Multivariate analysis of assemblage structure

116 Non-parametric multidimensional scaling (MDS) was used as the ordination method for

117 exploring changes in amphipod and macroalgal assemblages (Clarke and Warwick,

118 1994). The similarity matrix, which was calculated using the Bray-Curtis index and

119 double square transformation of data, was used to construct bivariate MDS plots.

120 Calculation of percentage similarities (SIMPER) was then applied to calculate the

121 contribution of each species to the dissimilarity between sampling times and habitats.

122 (PRIMER software; Clarke, 1993).

123

$124 \quad$ 2.3.2. Univariate analysis 
125 Algal biomass, $C$. racemosa biomass, species richness of seaweeds, biomass of detritus,

126 total abundance of amphipods, species richness of amphipods and abundance of seven

127 amphipod species (the most important by SIMPER) were analysed using ANOVA. To

128 test whether the abundance of amphipods was similar across habitats and times we used

129 an analysis of variance (ANOVA) which incorporated the following factors: 'Time of

130 sampling', a fixed factor and orthogonal, with two treatments: September-04 and

131 March-05; 'habitat', a fixed factor, with two treatments: macroalgal community with $C$.

132 racemosa (invaded habitat) and without C. racemosa (non-invaded habitat), and 'Site',

133 a random factor and nested with the both main factors, with three random sampling

134 sites.

135 Prior to ANOVA, heterogeneity of variance was tested with Cochran's $C$-test. Data

136 were $\sqrt{ } x+1$ transformed if variances were significantly different at $\mathrm{p}=0.05$, and $\log (x$

$137+1)$ transformed if variance was still heterogeneous. Where variance remained

138 heterogeneous, untransformed data were analysed, as ANOVA is a robust statistical test

139 and is relatively unaffected by heterogeneity of variances, particularly in balanced

140 experiments (Underwood, 1997), however, in such cases special care was taken in the

141 interpretation of results. Furthermore, in such cases, to reduce type I error, the level of

142 significance was reduced to $<0.01$. When ANOVA indicted a significant difference for

143 a given factor, the source of difference was identified by applying the Student-Newman-

144 Keul (SNK) test (Underwood, 1981; Underwood, 1997).

146 3. Results

147 3.1. Habitat features

148 A total of 24 taxa of macroalgae and one seagrass species were identified (Table 1).

149 Species richness showed significant seasonal differences (Table 2; Ti=P<0.05). During 
150 September, the invaded habitat showed a reduced number of macroalgal species: only

151 five together with $C$. racemosa, compared with 11 species recorded from the non152 invaded habitat. The most important species in terms of biomass in the non-invaded 153 places were Jania rubens, Halopteris scoparia and Cystoseira brachicarpa, while in the 154 invaded habitat C. racemosa, Jania rubens and Padina pavonica were most important 155 (Table 1). In March, differences between invaded and non-invaded habitats were lower 156 (14 where C. racemosa was present and 16 species where it was absent). The most 157 important species in non-invaded sites during March were Corallina ellongata, Jania 158 rubens and Dictiota fasciola; and C. racemosa, Cladophora sp. and Halopteris scoparia 159 dominated at invaded sites (Table 1). The MDS two-dimensional representation of 160 macrophyte biomass clearly showed segregation of sampling sites mainly related to 161 sampling time and habitat (Fig. 2).

162 In the case of algal biomass, excluding $C$. racemosa, significant differences were 163 noted for the invaded habitat with respect to the non-invaded habitat (Table 2; Fig. 3).

164 Total algal biomass recorded in September was similar between the two different 165 habitats $\left(347.67 \pm 117.44 \mathrm{~g} \mathrm{dw} \mathrm{m}^{-2}\right.$ for non-invaded habitat compared to $379.55 \pm 64.63$ $166 \mathrm{~g} \mathrm{dw} \mathrm{m}^{-2}$ for invaded habitat; Table 1), however, $C$. racemosa contributed a high value 167 (74.6\%), and replacing other native species. Non-invaded sites showed the highest mean 168 biomass value, which reached a maximum value of $826.46 \pm 203.15$ in September (Fig. 169 3). However, total biomass $\left(326.52 \pm 79.21 \mathrm{~g} \mathrm{dw} \mathrm{m}^{-2}\right)$ at the invaded sites, without a 170 recovery of the community in spite of the reduction of $C$. racemosa biomass.

171 Differences in accumulated detritus biomass was significant between habitats $172(P<0.05$, Table 2$)$. The highest values were recorded from invaded habitats during both 173 sampling periods (472.48 $\mathrm{g} \mathrm{dw} \mathrm{m}^{-2}$ in September and $466.92 \mathrm{~g} \mathrm{dw} \mathrm{m}^{-2}$ in March). On 174 the other hand, detritus biomass was relatively low at non-invaded habitats during 
175 September $\left(5.87 \pm 1.51 \mathrm{~g} \mathrm{dw} \mathrm{m}^{-2}\right)$, and higher in March $\left(242.22 \pm 47.25 \mathrm{~g} \mathrm{dw} \mathrm{m}^{-2}\right.$; Fig. $1763)$.

177

178 3.2. Amphipod assemblage

179 A total of 31 amphipod taxa, belonging to 13 families, were recorded (Table 3 ).

180 Species richness was significantly different (Ti, $P<0.05$, Table 4; Fig. 4a) among

181 sampling times but similar between habitats. In September, species richness recorded

182 from the habitat dominated by C. racemosa was similar to that recorded from the non-

183 invaded habitat (16 and 14 species respectively; Table 3), while for both habitats, values

184 were higher in March (20 and 24 species, Table 3). Only ten species were present in

185 both habitats and in both months: Amphilochus neapolitanus, Ampithoe ramondi,

186 Microdeutopus spp., Caprella spp., Apocorophium acutum, Elasmopus spp., Lysianassa

187 costae, Pereionotus testudo, Stenothoe monoculodes and Hyale schmidti. Seven species

188 were found only in the non-invaded habitats: Amphilochus sp., Ampelisca

189 serraticaudata, Ampithoe ferox, Lembos sp., Leptocheirus guttatus, Lysianassa sp. and

190 Stenothoe tergestina; while there seemed to be a relationship between the invaded

191 habitat and the following six amphipods: Ampelisca diadema, Corophium spp.

192 Corophium insidiosum, Gammarella fucicola, Melita palmata and Orchomene humilis.

193 Total abundance was similar between habitats in September, but there were significant

194 differences between the two habitats in March, with a maximum value of 6497.22

$195 \mathrm{ind} / \mathrm{m}^{2}$ recorded from the non-invaded habitat (Ti x Ha $P<0.01$, Table 4; Fig. 4b).

196 The two-dimensional MDS plot for the amphipod assemblages showed

197 segregation of sampling sites that was mainly related to the sampling period, while

198 moderate segregation was noted by habitat type during March (Fig. 5). The main 
199 species responsible for dissimilarities in amphipod assemblages were Caprella spp.,

200 Ampithoe ramondi, Microdeutopus spp., Elasmopus spp., Apocorophium acutum, Hyale

201 schmidti and Lysianassa costae, for which an average dissimilarity of $64.73 \%$ was

202 noted between habitats. Together, these species comprised $90 \%$ of the total amphipod 203 abundance.

The seven most important amphipod species showed different patterns of abundance values with respect to macroalgal assemblage. Abundance of Ampithoe ramondi and Hyale schmidti were significantly higher in non-invaded habitats (Ha,

$207 P<0.05$, Table 4; Fig. 6a, b). On the other hand, Apocorophium acutum had a 208 significantly higher abundance in the invaded habitat (Ha, $P<0.05$, Table 4; Fig. 6c). 209 Significant differences were recorded for Microdeutopus spp. in terms of sampling 210 times (Ti, $P<0.05$, Table 4; Fig. 6d), while it was more abundant in September at 211 invaded habitats but without significant differences.

212 With regard to differences between sampling times (Table 3), several species 213 appeared only in September (Amphilochus sp., Melita palmata and Orchomene 214 humilis); or in March (Ampelisca diadema, Ampelisca serraticaudata, Lembos sp., 215 Leptocheirus guttatus, Corophium spp., Corophium insidiosum, Dexamine spiniventris, 216 Gammarella fucicola, Melita hergensis, Lysianassa sp. and Stenothoe tergestina). 217 Dissimilarity between sampling times within non-invaded sites was not very high 218 (48.09\%); the most important species contributing to this dissimilarity were Caprella 219 spp. and Hyale schmidti. Dissimilarity between sampling times within invaded sites was $22051.71 \%$, the most important species contributing to this dissimilarity were Caprella spp. 221 and Lysianassa costae. 
223 significantly different between the two habitat types, but there was a clear pattern of 224 higher abundances in non-invaded habitat. The abundance of Caprella spp. varied 225 significantly with respect to season, being more abundant in March, especially in the 226 non-invaded habitat (Ti, $P<0.05$, Table 4; Fig. 6e). Elasmopus spp. seemed to be more 227 abundant on native seaweeds, especially during September, but not statistical 228 differences were noted (Table 4, Fig. 6f). Finally, the abundance of Lysianassa costae, 229 was higher in non-invaded habitats, but this was true only in March (TixHa, $P<0.01$,

230 Table 4, Fig. 6g); the pattern was opposite during September, but without any significant differences.

\section{Discussion}

Our results show that the presence and abundance of $C$. racemosa had a marked effect on the macroalgal assemblage structure of Mediterranean shallow rocky communities, affecting the species composition of vegetation and increasing the detritus stock. This causes important changes in the associated amphipod assemblage, in terms of both abundance and species composition. The effects of the invasive species on habitat structure were more important in September because the alga was dominant at that time. The seasonal variation in abundance values for $C$. racemosa recorded from our study area was similar to that described in other localities, i.e. with maximum

242 development in the warm season, while biomass values were similar or even greater 243 than those recorded from other Mediterranean localities (Piazzi and Cinelli, 1999). The 244 peculiar growth of C. racemosa, with stolons that spread rapidly in all directions, and its 245 colonisation pattern that results from sexual reproduction (Panayotidis and Žuljevič, 246 2001), together with dispersal of fragments detached from the plant (Ceccherelli et al., 
2001; Ceccherelli and Piazzi, 2001) and propagules (Renoncourt and Meinesz, 2002)

248 permit $C$. racemosa to colonize a habitat very efficiently. This results in strong 249 modification of habitat structure, particularly that of macroalgal assemblages. On the SE 250 coast of Spain and other locations (e.g. Nervi, Italy; Modena et al., 2000), colonisation

251 by $C$. racemosa has been mostly recorded from rocky bottom habitats located in 252 shallow waters $(0.5 \mathrm{~m})$, however, on a wider scale across the Mediterranean region (e.g. 253 France, Italy and Cyprus) more extensive spread of the alga have been recorded on soft 254 bottom habitats in deeper waters (15-20 m) (Argyrou et al., 1999; Verlaque et al., 2004), and on dead matte of Posidonia oceanica. Therefore, one would expect that the spread of $C$. racemosa will extend to both rocky and soft bottom habitats, as well as to degraded $P$. oceanica meadows.

With respect to changes in vegetation resulting from the presence of C. racemosa, an important reduction in species richness was recorded in September. On the other 260 hand, contrary to results from other studies (Piazzi et al., 2001), species richness was 261 similar between invaded and non-invaded habitats in March (the colder month), which implies that some native species colonized the habitat irrespective of the different species composition and biomass of benthic vegetation. Some authors have shown that several years are necessary for the development of dense and continuous $C$. racemosa stands (Ruitton et al., 2005); possibly during the forthcoming years the effects will persist also during the coldest period at the study area, reducing the possibility of algae

267 colonization. However, the total biomass of C. racemosa recorded from our study (259 $268 \mathrm{~g} \mathrm{dw} \mathrm{m}^{-2}$ ) is comparable or higher than that recorded from studies carried out on French 269 and Italian coasts, and is also higher than values obtained for $C$. taxifolia and $C$. 270 prolifera meadows at some localities (see a review in Capiomont et al., 2005). 
One of the remarkable impacts of $C$. racemosa is the accumulation of detritus,

272 which persists throughout the year. In spite of the important seasonal variability of $C$.

273 racemosa biomass, detritus accumulation persist in winter. The mesh generated by the 274 stolons of this species ensure that detritus is retained, while the multilayered structure

275 formed by the thallus traps the sediment (Piazzi et al., 2001). Detritus values recorded

276 during both seasons were 2 to 6 times higher than those recorded from native seaweeds.

277 This accumulation of detritus causes import changes in the structure of the sediment and

278 in the granulometric composition (Walker et al., 1991), leading to anoxic conditions in

279 which toxic substances can be possibly accumulated. On the other hand, detritus plays a

280 very important role as a trophic resource for marine invertebrates, being one of the main

281 trophic pathways of the marine ecosystem (Valiella, 1995) and is one of the most

282 important features of habitat structure in vegetated habitats (Allesina et al., 2005).

283 Therefore, any modification of the detritus compartment can affect the overall trophic

284 web, because it could lead to a change in the faunal assemblage structure resulting from

285 modification of trophic guilds due to different trophic requirements.

286 With respect to the epifauna, various studies have demonstrated that modification 287 of habitat complexity affects crustacean assemblages (Hicks, 1977, 1982; Stoner, 1980;

288 Virnstein, 1987; Virnstein and Howard, 1987; Edgar, 1983, 1992; Sanchez-Jerez et al., 289 1999; Ayala and Martín, 2003). In our study, the amphipod assemblages were affected 290 by changes in habitat structure due to colonisation by C. racemosa. The total abundance

291 of amphipods was greater on native seaweeds, mainly in March. However, the species 292 richness of the amphipod assemblage did not decrease because of the spread of $C$. 293 racemosa but because of an indirect effect; namely the increase in detritus biomass in 294 invaded habitat resulted in an increase in the abundance of detritivores species (e.g. 295 Apocorophium acutum), and increase in the abundance of herbivorous species (e.g. 
Ampithoe ramondi and Hyale schmidti), hence resulting in a large overall modification

297 of the assemblage species composition.

298 The main modification in amphipod assemblage structure was manifested as an

299 increase in abundance of Apocorophium acutum in habitat invaded by C. racemosa,

300 which was four times higher than that of other Corophiidae species in eutrophic habitats

301 (Guerra-García and García-Gómez, 2005). Species belonging to the genus

302 Apocorophium are tube-dwelling amphipods that inhabit small U-shaped tubes and are

303 selective deposit feeders (Ciarelli et al., 1997), and feed on bacteria, algae, and diatoms

304 adsorbed onto the surface of sediment particles (Meadows and Reid, 1966). Several

305 species of this genus are continuously exposed to toxicants in the sediment, which they

306 ingest while feeding (Bat and Raffaelli, 1998), hence they have been used for sediment

307 toxicity tests. The accumulation of detritus in habitats invaded by C. racemosa seems to

308 favour colonization by Corophium spp., resulting in a dramatic increase in abundance

309 and establishment of a large population in an altered habitat. Microdeutopus spp. also

310 showed a small increase in abundance in habitat invaded by C. racemosa, but the effect

311 was only recorded in September. This genus is generally associated with Posidonia

312 oceanica and fine sand habitats (Ruffo, 1982), but in experiments carried out recently

313 by Roberts and Poore (2005), the family Aoridae were noted to prefer bare rock with a

314 thin cover of sediment than an algal substratum. Furthermore, other taxonomic groups,

315 such as the polychaetes, are favoured by accumulation of detritus amongst the $C$.

316 racemosa stolons, as shown by Argyrou et al. (1999) from their study carried out in 317 Cyprus.

318 On the other hand, the abundance of some species, such as Ampithoe ramondi, 319 Hyale schmidti or Caprella spp., was reduced in habitat invaded by C. racemosa, since 320 these species have a preference for native seaweeds (Kocatas, 1976; Russo, 1997; 
321 Guerra-Garcia and García-Gómez, 2001; Roberts and Poore, 2005). Other studies have

322 also shown displacement of Ampithoe ramondi resulting from the presence of other

323 Caulerpa species, e.g. Caulerpa prolifera (Sánchez-Moyano et al., 2001). The displaced

324 species have a close relationship with seaweeds, as has been demonstrated by Viejo

325 (1999). In the case of other species, such as Lysianassa costae, the effects of $C$.

326 racemosa seem to be seasonal, inhabiting habitats that have a large algal biomass,

327 irrespective of the species composition.

328 Comparing the results of the present study with ones on the effects of C. taxifolia

329 on amphipod assemblages, the species richness recorded from the latter appears to be

330 lower (Bellan-Santini et al., 1995). Furthermore, the effects of C. taxifolia on the

331 abundance of amphipods also seem to be more critical (Bellan-Santini et al, 1995). Such

332 differences could be due to several factors, such as the species composition of Caulerpa

333 beds. Stands of $C$. taxifolia are monospecific, while in our case; the C. racemosa grew

334 intermixed with other macroalgal species during both sampling periods. Consequently,

335 during the initial stages of invasion of a host habitat by an invasive seaweed, an

336 increment in habitat complexity will occur if the initial cover is low, hence a new and

337 additional habitat for the local epifauna becomes available (Viejo, 1999). However, if

338 growth of the invasive species continues, leading to a monospecific and dense meadow,

339 it could lead to impoverishment of the amphipod assemblage as has been noted for $C$.

340 taxifolia elsewhere.

341 Several studies have demonstrated that consequences of $C$. racemosa in host 342 systems are very important, particularly since it appears that this introduced species

343 most invasive in the Mediterranean Sea (Verlaque et al., 2003). The presence of $C$.

344 racemosa in the southeastern coast of Spain is an incipient problem. It was recorded

345 from Alicante in 2002 and, in less than three years, important changes in the structure of 
346 shallow rocky habitat assemblages occurred, although to date the distribution of $C$.

347 racemosa has been rather patchy, hence its effects are not very widespread locally.

348 Several years may be necessary for development of a dense and continuous C. racemosa

349 meadow (Ruitton et al., 2005); therefore in the near future, one can expect dramatic

350 changes in rocky bottom habitats, leading to a direct impact on marine benthic

351 communities along the western Mediterranean coast. It is therefore very important to

352 increase our research effort to establish the ecological implications of the spread of $C$.

353 racemosa in the Mediterranean Sea, as this will provide the necessary information and

354 tools to develop new mitigation and eradication programs.

355

\section{5. Acknowledgements}

357 This work was supported by Instituto Alicantino de Cultura Juan Gil Albert, Excma.

358 Diputación de Alicante. We would like to thank Judith Klein and Marc Verlaque,

359 Centro Oceanológico de Marsella (Université de la Mediterranée, Parc Scientifique et

360 Technologique de Luminy) for identify the variety of C. racemosa present along the

361 coast of Alicante. We also thank several colleagues for their assistance in the field. We

362 are very grateful to Joseph A Borg to improve the English version and for his 363 comments. 
Allesina, S., Bondavalli, C., Scharler, U.M., 2005. The consequences of the aggregation of detritus pools in ecological networks. Ecological Modelling 189, 221-232.

Argyrou, M., Demetropoulos, A., Hadjichristophorou, M., 1999. Expansion of the macroalga Caulerpa racemosa and changes in soft bottom macrofaunal assemblages in Moni Bay, Cyprus. Oceanologica Acta 22, 517-528.

Ayala, Y., Martín, A., 2003. Relaciones entre la comunidad de anfípodos y las macroalgas a las que están asociados, en una plataforma rocosa del litoral central de Venezuela. Boletín Instituto Español Oceanografía 19 (1-4), 171-183.

Bat, L., Raffaelli, D., 1998. Sediment toxicity testing: a bioassay approach using the amphipod Corophium volutator and the polychaete Arenicola marina. Journal of Experimental Marine Biology and Ecology 226, 217-239.

Bellan-Santini, D., 1980. Relationship Between Populations of Amphipods and Pollution. Marine Pollution Bulletin 11, 224-227.

Bellan-Santini, D., 1995. Faune d'invertébrés du peuplement à Caulerpa taxifolia .

Données préliminaires pour les côtes de provence (Méditerranée nord-occidentale) Biologia Marina Mediterranea Vol 2, fasc 2 «Atti XXV Congresso »

Capiomont, A., Breugnot, E., den Haan, M., Meinesz, A., 2005. Phenology of a deep-water population of Caulerpa racemosa var. cylindracea in the northwestern Mediterranean Sea. Short communication. Botanica Marina 48, 80-83.

Cavas, L., Baskin, Y., Yurdakoc, K., Olgun, N., 2006. Antiproliferative and newly attributed apoptotic activities from an invasive marine alga: Caulerpa racemosa var. cylindracea. Journal of Experimental Marine Biology and Ecology 339, 111119.

Ceccherelli, G., Piazzi, L., Cinelli, F., 2001. The role of vegetative fragments in the recruitment process of Caulerpa taxifolia and Caulerpa racemosa. In: Gravez V, Ruitton S, Boudouresque CF, Le Direac'h L, Meinesz A, Scabbia G, Verlaque M (eds) Fourth International Workshop on Caulerpa taxifolia. GIS Posidonie Publ, Marseilles, France, pp 111-117.

Ceccherelli, G., Piazzi, L., 2001. Caulerpa racemosa e Caulerpa taxifolia in Mediterraneo: effetto della complessita dei popolamenti macroalgali autoctoni e dei loro rapporti competitivi. 328 Congresso SIBM, p 45.

Ciarelli, S., Vonck, WAPMA., van Straalen, N.M., 1997. Reproducibility of spikedsediment bioassays using the marine benthic amphipod, Corophium volutator. Marine Environmental Research 4, 329-343. 
Clarke, K.R., Warwick, R.M., 1994. Changes in Marine Communities: an approach to statistical analysis and interpretation. Natural Environment Research Council UK, $144 \mathrm{pp}$.

Connell, J.H., 1972. Community interactions on marine rocky intertidal shores. Annual Review of Ecology and Systematics 3, 169-192.

Conradi,M.; López-González,P.J.; García-Gómez,J.C., 1997. The Amphipod Community as a Bioindicator in Algeciras Bay (Southern Iberian Peninsula) Based on a Spatio-Temporal Distribution. Marine Ecology 18 (2), 97-111.

Dean, R.L., Conell, J.H., 1987. Marine invertebrates in algal succession. II. Test of hypotheses to explain changes in diversity with succession. Journal of Experimental Marine Biology and Ecology 109, 217-247.

Edgar, G.J., 1983. The ecology of South-East Tasmanian phytal animal communities. IV. Factors affecting the distribution of ampithoid amphipods among algae. Journal of Experimental Marine Biology and Ecology 70, 205-225.

Edgar, G.J., 1990. The influence of plant structure on the species richness, biomass and secondary production of macrofaunal assemblages associated with Western Australian seagrass beds. Journal of Experimental Marine Biology and Ecology $137,215-240$.

Edgar, G.J., 1992. Patterns of colonization of mobile epifauna in Western Australian seagrass bed. Journal of Experimental Marine Biology and Ecology 157, 225-246.

Ferrandis-Ballester, E., and Bartolomé-Pina, F., 1985. Dulces bárbaros del este y del oeste (Análisis estadísticos de los vientos en la bahía de Alicante). In: Ramos, A. A. (Ed.). La reserva marina de la Isla Plana o Nueva Tabarca (Alicante), 51-93 pp.

Guerra-García, J.M., García-Gómez, J.C., 2001. The spatial Distribution of Caprellidea (Crustacea: Amphipoda): A Stress Bioindicator in Ceuta (North Africa, Gibraltar Area). Marine Ecology 22, 357-367.

Guerra-García, J.M., García-Gómez, J.C., 2005. Oxygen levels versus chemical pollutants: do they have similar influence on macrofaunal assemblages? A case study in a harbour with two opposing entrances. Environmental Pollution 135, 281-291.

Hicks, G.R.F., 1997. Observations of substrate preference of marine phytal harpacticoids (Copepoda). Hydrobiology 56, 7-9.

Hicks, G.R.F., 1982. Habitat structure, disturbance, and equilibrium in crustacean communities. Marine Ecology 3, 41-45.

Johnson, M., 1970. Variations in diversity within benthic marine communities. American Naturalist 104, 285-308.

Kocatas, A., 1976. Note préliminaire sur les amphipodes recueillis dans les horizons supérieurs de l'étage infralitoral rocheux du Golfe d'Izmir (Turquie). Tethys 7 (23), 235-240. 
Meadows, P.S., Reid, A., 1966. The behaviour of Corophium volutator. Journal of Zoology London 150, 387-399.

Modena, M., Matricardi. G., Vacchi, M., Guidetti, P., 2000. Spreading of Caulerpa racemosa (Forsskål) J. Agardh (Bryopsidaceae, Chlorophyta) along the coasts of the Ligurian Sea. Cryptogamie Algologie 21, 301-304.

Panayotidis, P., Žuljevič, A., 2001. Sexual reproduction of the invasive green alga Caulerpa racemosa var. occidentalis in the Mediterranean Sea. Oceanologica Acta 24, 199-203.

Pena-Martín, C., Cristóbal-Fernanz, J.C., Crespo, M.B., 2003. Caulerpa racemosa (Forssk.) J Agardh (Caulerpaceae, Chlorophyceae), nueva para la flora de Alicante. Anales Jardín Botánico de Madrid 60 (2), 448-449.

Piazzi, L., Balata, D., Ceccherelli, G., Cinelli, F., 2001. Comparative study of the growth of two co-occurring introduced green algae Caulerpa taxifolia and Caulerpa racemosa along the Tuscan coast (Italy, western Mediterranean). Cryptogamie Algologie 22, 459-466.

Piazzi, L., Balata, D., 2007. The spread of Caulerpa racemosa var. cylindracea in in the Mediterranean Sea: an example of how biological invasions can influence beta diversity. Marine Environmental Research (2007), doi:10.1016/j.marenvres.2007.07.002

Piazzi, L., Cinelli, F., 1999. Développement et dynamique saisonnière d'un peuplement méditerranéen de l'algue tropicale Caulerpa racemosa (Forsskål) J. Agardh. Cryptogamie Algologie 20 (4), 295-300.

Piazzi, L., Meinesz, A., Verlaque, M., Akçali, B., Antoli'c, B., Argyrou, M., Balata, D., Ballesteros, E., Calvo, S., Cinelli, F., Cirik, S., Cossu, A., D'Archino, R., Djellouli, A.S., Javel, F., Lanfranco, E., Mifsud, C., Pala, D., Panayotidis, P., Peirano, A., Pergent, G., Petrocelli, A., Ruitton, S., Žuljevi'c, A., Ceccherelli, G. 2005. Invasion of Caulerpa racemosa var. cylindracea (Caulerpales, Chlorophyta) in the Mediterranean Sea: an assessment of the spread. Cryptogamie Algologie 26 (2), 189-202.

Renoncourt, L., Meinesz, A., 2002. Formation of propagules on a invasive strain of Caulerpa racemosa (Chlorophyta) in the Mediterranean Sea. Phycologia 5, 533535.

Roberts, D.A., and Poore, A.G.B., 2005. Habitat configuration affects colonisation of epifauna in marine alga bed. Biological Conservation 127, 18-26.

Ruffo, S., (ed) 1982. The Amphipoda of the Mediterranean. Part 1, Gammaridea. Mémoires de l'Institut Océanographique, Monaco 13 :364 pp.

Ruitton, S., Verlaque, M., Boudouresque, C.F., 2005. Seasonal changes of the introduced Caulerpa racemosa var. cylindracea (Caulerpales, Chlorophyta) at the northwest limit of its Mediterranean range. Aquatic Botany 82, 55-70. 
Russo, A.R., 1997. Epifauna living on sublittoral seaweeds around Cyprus. Hidrobiología 344, 169-179.

Sanchez-Jerez, P., Barberá-Cebrián, C., Ramos-Esplá, A.A., 1999. Comparison of the epifauna spatial distribution in Posidonia oceanica, Cymodocea nododa and unvegetated bottoms: Importance of meadow edges. Acta Oecologica 20, 391-405.

Sanchez-Jerez, P., Barberá-Cebrián, C., Ramos-Esplá, A.A., 2000. Influence of the structure of Posidonia oceanica meadows modified by bottom trawling on crustacean assemblages: comparison of amphipods and decapods. Scientia Marina 64, 319-326.

Sánchez-Moyano, J.E., Estacio, J.F., García-Adiego, E.M., García-Gómez, J.C., 2001. Effect of the vegetative cycle of Caulerpa prolifera on the spatio-temporal variation of invertebrate macrofauna. Aquatic Botany 70, 163-174.

Stål, J., Pihl, L., Wennhage, H., 2006. Food utilisation by coastal fish assemblages in rocky and soft bottoms on the Swedish west coast: Inference for identification of essential fish habitats. Estuarine Coastal and Shelf Science doi: 10.1016/j.ecss.2006.09.008

Stoner, A.W., 1980. Perception and choice of substratum by epifaunal amphipods associated with seagrasses. Marine Ecology Progress Series 3, 105-111.

Taylor, R.B., Cole, R.G., 1994. Mobile epifauna on subtidal brown seaweeds in northeastern New Zealand. Marine Ecology Progress Series 115, 271-282.

Underwood, A.J., 1981. Techniques of analysis of variance in experimental biology and ecology. Oceanography and Marine Biology. An Annual Review 19, 513-605.

Underwood, A.J., 1997. Experiments in Ecology: Their Logical Design and Interpretation Using Analysis of Variance, Cambridge University Press, 504 p.

Valiela, I., 1995. Marine Ecological Processes. Springer, Verlag New York.

Verlaque, M., Alfonso-Carrillo, J., Gil-Rodriguez, M.C., Durand, C., Boudouresque, C.F., and Le Parco, Y., 2004. Blitzkrieg in a marine invasion: Caulerpa racemosa var. cylindracea (Bryopsidales, Chlorophyta) reaches the Canary Islands (northest Atlantic). Biological Invasions 6, 269-281.

Verlaque, M., Durand, C., Huisman, J.M., Boudouresque, C.F., Le Parco, Y., 2003. On the identity and origin of the Mediterranean invasive Caulerpa racemosa (Caulerpales, Chlorophyta). European Journal of Phycology 38, 325-339.

Viejo, R.M., 1999. Mobile epifauna inhabiting the invasive Sargassum muticum and two local seaweeds in northern Spain. Aquatic Botany 64, 131-149.

Virnstein, R.W., 1987. Seagrass-associated invertebrate communities of the Southeastern U S A: a review. Florida Marine Research Publication 42, 89-116. 
Virnstein, R.W., Howard, R.K., 1987. Motile epifauna of marine macrophytes in the Indian River Lagoon, Florida. I. Comparisons among three species of seagrasses from adjacent beds. Bulletin of Marine Sciences 41, 1-12.

519 Walker, D.I., Hutchings, P.A., Wells, F.E., 1991. Seagrass, sediment and infauna: a comparison of Posidonia australis, Posidonia sinuosa and Amphibolis antarctica in Princess Royal Harbour, south-western Australia. I. Seagrass biomass, productivity and contribution to sediments. In: Wells, F.E., Walker, D.I., Kirkman, H., Lethbridge, R., (eds), The Marine Flora and Fauna of Albany, W Australia, Vol 2 W Australian Museum, Perth, pp 597-610. 
Table 1 Mean biomass $\left(\mathrm{g} \mathrm{dw} \mathrm{m}^{-2}\right)$ values $\pm \mathrm{SE}$ for the different species, together with total biomass, total species richness and detritus weight for the two sampling periods and habitats.

528

\begin{tabular}{|c|c|c|c|c|c|}
\hline & \multirow{2}{*}{ Species } & \multicolumn{2}{|c|}{ SEPTEMBER - 04} & \multicolumn{2}{|c|}{ MARCH - 05} \\
\hline & & $\begin{array}{c}\text { Non-invaded } \\
\text { habitat }\end{array}$ & $\begin{array}{c}\text { Invaded } \\
\text { habitat }\end{array}$ & $\begin{array}{c}\text { Non-invaded } \\
\text { habitat }\end{array}$ & $\begin{array}{c}\text { Invaded } \\
\text { habitat }\end{array}$ \\
\hline \multirow[t]{9}{*}{ Chlorophyta } & Acetabularia acetabulum (Linnaeus) P.C. Silva & - & - & - & $0.08 \pm 0.06$ \\
\hline & Caulerpa prolifera (Forsskål) J.V. Lamouroux & $2.23 \pm 1.02$ & $19.4 \pm 10.57$ & - & $0.01 \pm 0.01$ \\
\hline & Caulerpa racemosa (Forsskål) J. Agardh & - & $259.49 \pm 65.99$ & - & $68.91 \pm 18.71$ \\
\hline & Cladophora sp. Kützing, 1843 & $0.30 \pm 0.30$ & - & $54.38 \pm 14.60$ & $98.19 \pm 28.9$ \\
\hline & Codium (cf) F.S. Collins \& Hervey, 1917 & - & - & $17.43 \pm 16.87$ & - \\
\hline & Dasycladus vermicularis (Scopoli) Krasser & $4.27 \pm 1.55$ & $0.78 \pm 0.36$ & & $0.99 \pm 0.63$ \\
\hline & Flabellia petiolata (Turra) Nizamuddin & - & - & $0.13 \pm 0.11$ & - \\
\hline & Halimeda tuna (J. Ellis \& Solander) J.V. Lamouroux & $0.09 \pm 0.09$ & - & $0.64 \pm 0.64$ & - \\
\hline & Ulva sp. Linnaeus & - & - & $5.46 \pm 1.64$ & $15.15 \pm 5.78$ \\
\hline \multirow[t]{8}{*}{ Phaeophyta } & Cladostephus spongiosus (Hudson) C. Agardh & - & - & $0.15 \pm 0.15$ & - \\
\hline & Colpomenia sinuosa (Mertens ex Roth) Derbès \& Solier & - & & $6.97 \pm 4.99$ & $3.94 \pm 3.93$ \\
\hline & Cystoseira brachicarpa J. Agardh & $34.75 \pm 23.07$ & - & - & - \\
\hline & Cystoseira compressa (Esper) Gerloff \& Nizamuddin & - & & $63.92 \pm 63.92$ & $0.71 \pm 0.71$ \\
\hline & Dictyota fasciola (Roth) J. V. Lamouroux & $1.51 \pm 0.97$ & 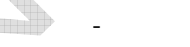 & $134.78 \pm 53.99$ & $20.72 \pm 17.44$ \\
\hline & Halopteris scoparia (Linnaeus) Sauvageau & $35.81 \pm 34.45$ & - & $104.82 \pm 57.53$ & $68.04 \pm 48.43$ \\
\hline & Padina pavonica (Linnaeus) Thivy & $20.31 \pm 6.86$ & $26.87 \pm 14.99$ & $44.14 \pm 34.64$ & $37.16 \pm 19.51$ \\
\hline & Sargassum vulgare C.Agardh & $2.13 \pm 2.13$ & - & $32.83 \pm 32.56$ & - \\
\hline \multirow[t]{7}{*}{ Rodophyta } & Ceramium spp. (Hudson) C.A. Agardh & $0.11 \pm 0.11$ & - & $10.72 \pm 8.78$ & - \\
\hline & Corallina ellongata Ellis et Solander & - & - & $186.77 \pm 175.87$ & $0.59 \pm 0.59$ \\
\hline & Halopitys incurvus (Hudson) Batters & - & $5.13 \pm 4.19$ & - & - \\
\hline & Jania rubens (Linnaeus) J.V. Lamouroux & $246.16 \pm 83.17$ & $67.87 \pm 29.74$ & $163.12 \pm 113.76$ & - \\
\hline & Laurencia pinnatifida (Hudson) Lamouroux & - & - & $1.24 \pm 1.24$ & - \\
\hline & Peyssonnelia sp. (S.G. Gmelin) Decaisne & - & - & - & $9.88 \pm 9.88$ \\
\hline & Alsidium corallinum (cf) C. Agardh & - & - & - & $0.29 \pm 0.29$ \\
\hline Seagrasses & Cymodocea nodosa (Ucria) Ascherson & - & - & - & $1.81 \pm 1.81$ \\
\hline \multicolumn{2}{|c|}{ Total biomass } & $347.67 \pm 117.44$ & $379.55 \pm 64.63$ & $826.49 \pm 203.15$ & $326.52 \pm 79.21$ \\
\hline \multicolumn{2}{|c|}{ Species richness } & 11 & 6 & 16 & 15 \\
\hline \multicolumn{2}{|l|}{ Detritus } & $5.87 \pm 1.51$ & $472.48 \pm 123.05$ & $242.22 \pm 47.25$ & $466.92 \pm 68.91$ \\
\hline
\end{tabular}




\section{ACCEPTED MANUSCRIPT}

530 Table 2 Result of ANOVA (three-factor) for the different habitat attributes: macrophyte species richness,

531 macrophyte biomass, macrophyte biomass without $C$. racemosa, and detritus. MS = mean square; $P=$

532 level of probability; $\mathrm{df}=$ degrees of freedom; $\mathrm{Si}=$ site; $\mathrm{ns}=$ non-significant; * significant at $p<0.05$

533

\begin{tabular}{|c|c|c|c|c|c|c|c|c|c|c|}
\hline \multirow[t]{2}{*}{ Source of variation } & & \multicolumn{2}{|c|}{$\begin{array}{l}\text { Species } \\
\text { richness }\end{array}$} & \multicolumn{2}{|c|}{$\begin{array}{l}\text { Macrophyte } \\
\text { biomass }\end{array}$} & \multicolumn{2}{|c|}{$\begin{array}{c}\text { Macrophyte } \\
\text { biomass without } \\
\text { C. racemosa } \\
\end{array}$} & \multicolumn{2}{|c|}{ Detritus } & \multirow[t]{2}{*}{$F$ versus } \\
\hline & & MS & $P$ & MS & $P$ & MS & $P$ & MS & $P$ & \\
\hline Sampling time $=\mathrm{Ti}$ & 1 & 53.78 & $0.0158 *$ & 6.59 & 0.2154 & 6.05 & 0.1066 & 191.75 & 0.3812 & Si(TixHa) \\
\hline Habitat=Ha & 1 & 2.78 & 0.5077 & 5.88 & 0.2395 & 10.04 & $0.0472 *$ & 1720.49 & $0.0241 *$ & $\mathrm{Si}(\mathrm{TixHa})$ \\
\hline ТіхНа & 1 & 11.11 & 0.2029 & 12.34 & 0.1030 & 0.27 & 0.7110 & 210.67 & 0.3599 & $\mathrm{Si}$ (ТixHa) \\
\hline $\mathrm{Si}$ (TixHa) & 8 & 5.78 & $0.0043 *$ & 3.64 & 0.0821 & 1.83 & $0.0002 *$ & 223.34 & $0.0001 *$ & Res \\
\hline Residual & 24 & 1.47 & & 1.77 & & 0.29 & & 31.75 & & \\
\hline \multirow{2}{*}{\multicolumn{2}{|c|}{$\begin{array}{l}\text { Cochran's C-test } \\
\text { Transformation }\end{array}$}} & \multirow{2}{*}{\multicolumn{2}{|c|}{$\begin{array}{c}\mathrm{C}=0.3585 \mathrm{~ns} \\
\text { None }\end{array}$}} & \multirow{2}{*}{\multicolumn{2}{|c|}{$\begin{array}{c}\mathrm{C}=0.3917 \mathrm{~ns} \\
\mathrm{Sqrt}(\mathrm{X}+1)\end{array}$}} & \multirow{2}{*}{\multicolumn{2}{|c|}{$\begin{array}{c}\mathrm{C}=0.2616 \mathrm{~ns} \\
\mathrm{Ln}(\mathrm{X}+1)\end{array}$}} & \multirow{2}{*}{\multicolumn{2}{|c|}{$\begin{array}{c}\mathrm{C}=0.3368 \mathrm{~ns} \\
\text { None }\end{array}$}} & \\
\hline & & & & & & & & & & \\
\hline
\end{tabular}


534

535

536

537

Table 3 Abundance of amphipod species (number of individuals per $\mathrm{m}^{2} \pm \mathrm{SE}$ ) recorded from the different habitats for each of the two different sampling periods, together with total abundance and species richness for the two sampling periods and habitats.

\begin{tabular}{|c|c|c|c|c|c|}
\hline \multirow[b]{2}{*}{ Family } & \multirow[b]{2}{*}{ Species } & \multicolumn{2}{|c|}{ SEPTEMBER - 04} & \multicolumn{2}{|c|}{ MARCH - 05} \\
\hline & & $\begin{array}{c}\text { Non-invaded } \\
\text { habitat }\end{array}$ & $\begin{array}{c}\text { Invaded } \\
\text { habitat }\end{array}$ & $\begin{array}{c}\text { Non-invaded } \\
\text { habitat }\end{array}$ & $\begin{array}{l}\text { Invaded } \\
\text { habitat }\end{array}$ \\
\hline \multirow{2}{*}{ Amphilochidae } & Amphilochus sp. Bate, 1862 & $5.56 \pm 5.56$ & - & - & - \\
\hline & Amphilochus neapolitanus Della Valle, 1893 & $2.78 \pm 2.78$ & $5.56 \pm 5.56$ & $50 \pm 25.0$ & $5.56 \pm 3.68$ \\
\hline \multirow[t]{2}{*}{ Ampeliscidae } & Ampelisca diadema (A. Costa, 1853) & - & - & - & $2.78 \pm 2.78$ \\
\hline & Ampelisca serraticaudata Chevreux, 1888 & - & & $2.78 \pm 2.78$ & \\
\hline \multirow[t]{2}{*}{ Amphithoidae } & Ampithoe ferox (Chevreux, 1902) & $2.78 \pm 2.78$ & - & $2.78 \pm 2.78$ & \\
\hline & Ampithoe ramondi Audouin, 1826 & $1619.44 \pm 426.08$ & $977.78 \pm 425.11$ & $830.56 \pm 262.69$ & $108.33 \pm 33.07$ \\
\hline \multirow[t]{3}{*}{ Aoridae } & Lembos spp. Bate, 1856 & - & - & $2.78 \pm 2.78$ & - \\
\hline & Leptocheirus guttatus (Grube, 1864) & - & - & $5.56 \pm 3.68$ & - \\
\hline & Microdeutopus spp. A. Costa, 1853 & $1130.56 \pm 286.47$ & $1433.33 \pm 401.11$ & $230.56 \pm 87.28$ & $230.56 \pm 35.3$ \\
\hline Caprellidae & Caprella spp. Lamarck, 1801 & $116.67 \pm 84.68$ & $2.78 \pm 2.78$ & $3744.44 \pm 1022.81$ & $1236.11 \pm 596.05$ \\
\hline \multirow[t]{4}{*}{ Corophiidae } & Corophium spp. Latreille, 1806 & - & - & - & $5.56 \pm 5.56$ \\
\hline & Apocorophium acutum (Chevreux, 1908) & $58.33 \pm 35.11$ & $402.78 \pm 108.29$ & $27.78 \pm 17.4$ & $172.22 \pm 108.45$ \\
\hline & Corophium insidiosum Crawford, 1937 & - & - & - & $2.78 \pm 2.78$ \\
\hline & Ericthonius brasiliensis (Dana, 1855) & - & $2.78 \pm 2.78$ & $22.22 \pm 15.28$ & $8.33 \pm 5.89$ \\
\hline \multirow[t]{4}{*}{ Dexaminidae } & Atylus massiliensis Bella-Santini, 1975 & - & $2.78 \pm 2.78$ & $105.56 \pm 35.79$ & - \\
\hline & Atylus guttatus (A. Costa, 1851) & $2.78 \pm 2.78$ & - & $100 \pm 60.42$ & $5.56 \pm 3.67$ \\
\hline & Dexamine spiniventris (A. Costa, 1853) & & - & $75 \pm 50.69$ & $44.44 \pm 36.03$ \\
\hline & Guernea coalita (Norman, 1868) & & $8.33 \pm 5.89$ & $41.67 \pm 21.25$ & - \\
\hline \multirow[t]{5}{*}{ Gammaridae } & Elasmopus spp. A. Costa, 1853 & $586.11 \pm 241.35$ & $272.22 \pm 87.35$ & $202.78 \pm 63.25$ & $97.22 \pm 40.7$ \\
\hline & Gammarella fucicola (Leach, 1814) & - & - & - & $2.78 \pm 2.78$ \\
\hline & Maera inaequipes (A. Costa, 1857) & - & $2.78 \pm 2.78$ & $11.11 \pm 8.45$ & $2.78 \pm 2.78$ \\
\hline & Melita hergensis Reid, 1939 & - & - & $16.67 \pm 13.82$ & $50 \pm 44.1$ \\
\hline & Melita palmata Montagu, 1804 & - & $2.78 \pm 2.78$ & - & - \\
\hline \multirow[t]{3}{*}{ Lysianassidae } & Lysianassa sp. & - & - & $13.89 \pm 9.42$ & - \\
\hline & Lysianassa costae Milne Edwards, 1830 & $127.78 \pm 45.54$ & $230.56 \pm 51.67$ & $258.33 \pm 64.28$ & $33.33 \pm 27.32$ \\
\hline & Orchomene humilis (A. Costa, 1853) & - & $25 \pm 17.68$ & - & - \\
\hline Oedicerotidae & Periculodes aequimanus (Kossman, 1880) & $5.56 \pm 3.68$ & - & $2.78 \pm 2.78$ & $8.33 \pm 5.89$ \\
\hline Phliantidae & Pereionotus testudo (Montagu, 1808) & $2.78 \pm 2.78$ & $2.78 \pm 2.78$ & $19.44 \pm 16.55$ & $13.89 \pm 11.11$ \\
\hline \multirow[t]{2}{*}{ Stenothoidae } & Stenothoe monoculoides (Montagu, 1813) & $63.89 \pm 30.08$ & $5.56 \pm 5.56$ & $77.78 \pm 27.15$ & $36.11 \pm 26.06$ \\
\hline & Stenothoe tergestina (Nebeski, 1880) & - & - & $5.56 \pm 5.56$ & - \\
\hline Talitridae & Hyale schmidti (Heller, 1866) & $52.78 \pm 38.74$ & $2.78 \pm 2.78$ & $605.56 \pm 198.55$ & $25 \pm 13.82$ \\
\hline Unidentified & & $5.56 \pm 5.56$ & - & $41.67 \pm 25.68$ & $38.89 \pm 30.65$ \\
\hline \multicolumn{2}{|c|}{ Total abundance } & $3861.11 \pm 925.18$ & $3383.33 \pm 844.11$ & $6497.22 \pm 1586.08$ & $2130.56 \pm 793.68$ \\
\hline \multicolumn{2}{|l|}{ Species richness } & 14 & 16 & 24 & 20 \\
\hline
\end{tabular}


539 Table 4 Results of ANOVA (three-factor) for amphipod species richness, total abundance, and

540 abundance of the seven most abundant species. MS = mean square; $P=$ level of probability; $\mathrm{df}=$ degrees 541 of freedom; $\mathrm{Si}=$ site, $\mathrm{ns}=$ non-significant; * significant at $p<0.05$

542

\begin{tabular}{|c|c|c|c|c|c|c|c|c|}
\hline \multirow{2}{*}{ Source of variation } & \multirow{2}{*}{ df } & \multicolumn{2}{|c|}{ Species richness } & \multicolumn{2}{|c|}{ Total abundance } & \multicolumn{2}{|c|}{ Ampithoe ramondi } & \multirow[t]{2}{*}{$F$ versus } \\
\hline & & MS & $P$ & MS & $\boldsymbol{P}$ & MS & $P$ & \\
\hline Sampling time $=\mathrm{Ti}$ & 1 & 78.03 & $0.0158 *$ & 6889.00 & 0.6864 & 13.28 & $0.0348 *$ & Si(TixHa) \\
\hline Habitat $=\mathrm{Ha}$ & 1 & 42.25 & 0.0551 & 84487.11 & 0.1807 & 12.04 & $0.0420 *$ & $\mathrm{Si}$ (TixHa) \\
\hline TixHa & 1 & 56.25 & $0.0321 *$ & 54444.44 & $0.0033^{*}$ & 2.47 & 0.3054 & $\mathrm{Si}$ (TixHa) \\
\hline Si (TixHa) & 8 & 8.39 & $0.0481 *$ & 39278.50 & $0.0033 *$ & 2.06 & $0.0028 *$ & Res \\
\hline Residual & 24 & 3.53 & & 9534.44 & & 0.48 & & \\
\hline Cochran's C-test & & $\mathrm{C}=0.1$ & $54 \mathrm{~ns}$ & $\mathrm{C}=0.2$ & $10 \mathrm{~ns}$ & $\mathrm{C}=0$. & $88 \mathrm{~ns}$ & \\
\hline Transformation & & $\mathrm{Nc}$ & & & & $\mathrm{Ln}$ & $+1)$ & \\
\hline \multirow[t]{2}{*}{ Source of variation } & \multirow[t]{2}{*}{ df } & \multicolumn{2}{|c|}{ Hyale schmidtii } & \multicolumn{2}{|c|}{$\begin{array}{c}\text { Apocorophium } \\
\text { acutum }\end{array}$} & \multicolumn{2}{|c|}{ Microdeutopus spp. } & IS \\
\hline & & MS & $P$ & MS & $P$ & MS & $P$ & \\
\hline Sampling time $=\mathrm{Ti}$ & 1 & 14.69 & $0.0104 *$ & 230.02 & 0.0980 & 23.49 & $0.0008 *$ & $\mathrm{Si}$ (TixHa) \\
\hline Habitat $=\mathrm{Ha}$ & 1 & 16.63 & $0.0076^{*}$ & 890.02 & $0.0062 *$ & 0.82 & 0.3590 & $\mathrm{Si}$ (TixHa) \\
\hline TixHa & 1 & 6.96 & 0.0511 & 132.25 & 0.1934 & 0.0003 & 0.9853 & $\mathrm{Si}$ (TixHa) \\
\hline $\mathrm{Si}$ (TixHa) & 8 & 1.32 & 0.0508 & 65.58 & 0.7064 & 0.87 & 0.0943 & Res \\
\hline Residual & 24 & 0.56 & & 96.77 & & 0.44 & & \\
\hline Cochran's C-test & & $\mathrm{C}=0.3$ & $41 \mathrm{~ns}$ & $\mathrm{C}=0.3$ & $20 \mathrm{~ns}$ & $\mathrm{C}=\mathrm{C}$ & ו & \\
\hline Transformation & & $\operatorname{Ln}(2$ & $+1)$ & & & & & \\
\hline \multirow{2}{*}{ Source of variation } & \multirow{2}{*}{ df } & \multicolumn{2}{|c|}{ Caprella spp. } & \multicolumn{2}{|c|}{ Elasmopus spp. } & \multicolumn{2}{|c|}{ Lysianassa costae } & $F$ versus \\
\hline & & MS & $P$ & MS & $P$ & MS & $P$ & \\
\hline Sampling time $=\mathrm{Ti}$ & 1 & 85069.44 & $0.0166^{*}$ & 15.39 & 0.1746 & 16.00 & 0.5058 & $\frac{\mathrm{Si}(\mathrm{TixHa})}{}$ \\
\hline Habitat $=\mathrm{Ha}$ & 1 & 24753.77 & 0.1420 & 8.57 & 0.2986 & 53.77 & 0.2374 & $\mathrm{Si}$ (TixHa) \\
\hline TixHa & 1 & 20640.11 & 0.1753 & 0.21 & 0.8648 & 386.77 & $0.0090 *$ & $\mathrm{Si}$ (TixHa) \\
\hline $\mathrm{Si}$ (TixHa) & 8 & 9331.33 & $0.0359 *$ & 6.93 & $0.0033 *$ & 32.97 & 0.5053 & Res \\
\hline Residual & 24 & 3650.83 & & 1.68 & & 35.19 & & \\
\hline Cochran's C-test & & \multirow{2}{*}{\multicolumn{2}{|c|}{$\begin{array}{c}\mathrm{C}=0.3862 \mathrm{~ns} \\
\text { None }\end{array}$}} & \multirow{2}{*}{\multicolumn{2}{|c|}{$\begin{array}{c}\mathrm{C}=0.2690 \mathrm{~ns} \\
\operatorname{Sqrt}(\mathrm{X}+1)\end{array}$}} & \multirow{2}{*}{\multicolumn{2}{|c|}{$\begin{array}{c}\mathrm{C}=0.3228 \mathrm{~ns} \\
\text { None }\end{array}$}} & \\
\hline Transformation & & & & & & & & \\
\hline
\end{tabular}

543

544 


\section{ACCEPTED MANUSCRIPT}

545

546

547

548

549

550

551

552

553

554

555

556

557

558

559

560

561

562

Fig. 1. Map showing the location of Alicante on the southeastern coast of Spain, and the study area.

Fig. 2. Two-dimensional MDS plot for algal biomass; S: September-04; M: March-05; I: Invaded habitat; NI: Non-invaded habitat, for each of the six sampling sites.

Fig. 3. Mean seaweed biomass $( \pm S E)$ recorded from the two different sampling periods and habitats. Seaweed = biomass of seaweeds (without $C$. racemosa); C. racemosa $=$ biomass of $C$. racemosa; and Detritus $=$ biomass of detritus.

Fig. 4. (a) Mean number of amphipod species (individuals $\mathrm{m}^{-2} \pm \mathrm{SE}$ ) and (b) total abundance (individuals $\mathrm{m}^{-2} \pm \mathrm{SE}$ ), recorded from the two different sampling periods and habitats.

Fig. 5. Two-dimensional MDS plot amphipod species abundance. $\mathrm{S}=$ September-04; $\mathrm{M}=\mathrm{March}-05$; $\mathrm{I}=$ Invaded habitat; NI = Non-invaded habitat for each of the six sampling sites.

Fig. 6. Mean abundance (number of individuals $\pm \mathrm{SE}$ ) of the seven most abundant amphipods: Ampithoe ramondi (a); Hyale schmidti (b); Apocorophium acutum (c); Microdeutopus spp. (d); Caprella spp. (e); Elasmopus spp. (f) and Lysianassa costae (g) 


\section{ACCEPTED MANUSCRIPT}

563

Figure 1
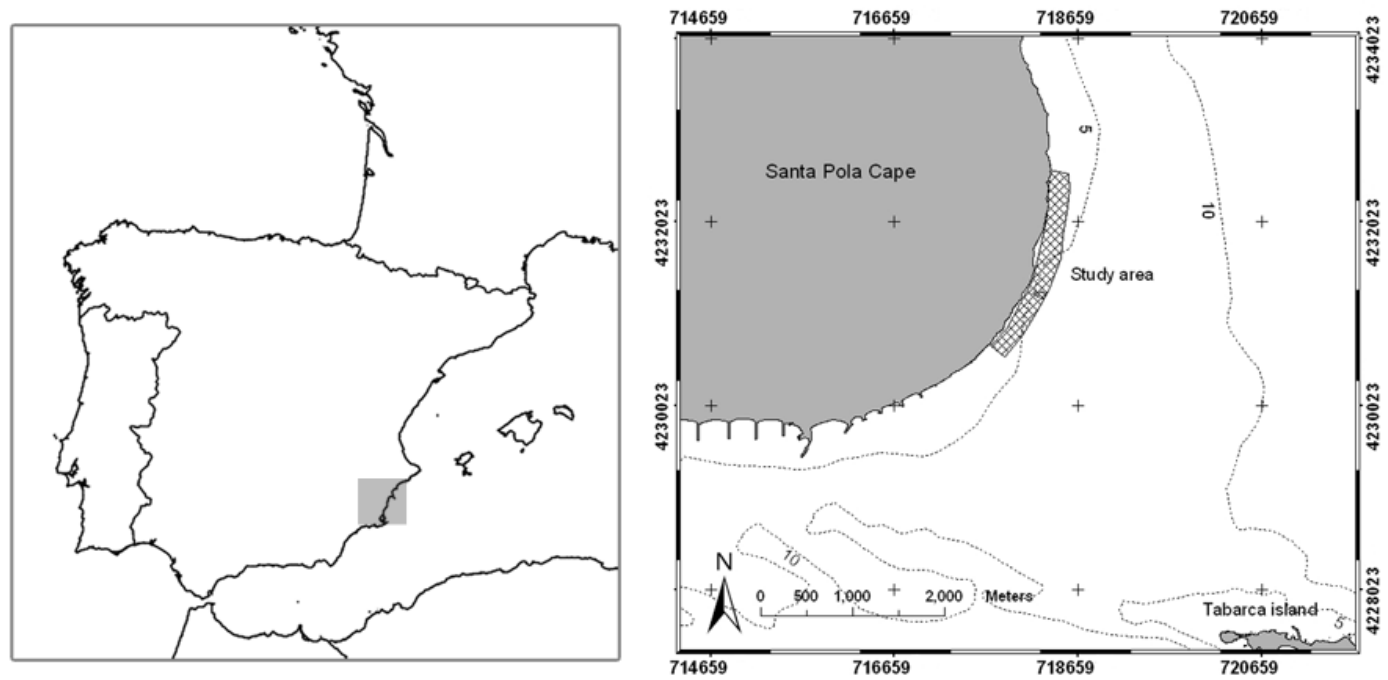

564

565 


\section{ACCEPTED MANUSCRIPT}

566

Figure 2

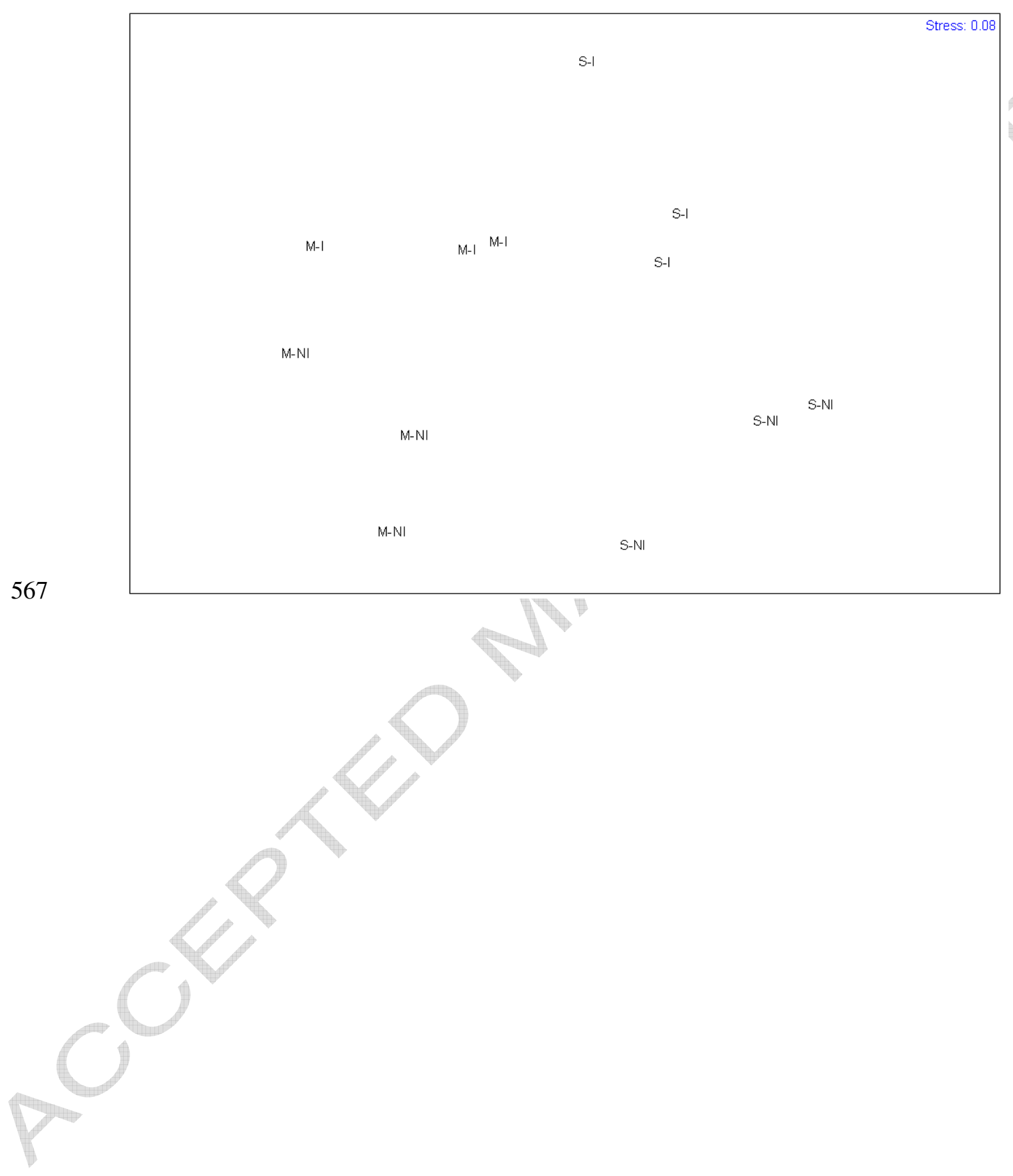




\section{ACCEPTED MANUSCRIPT}

568

Figure 3

569
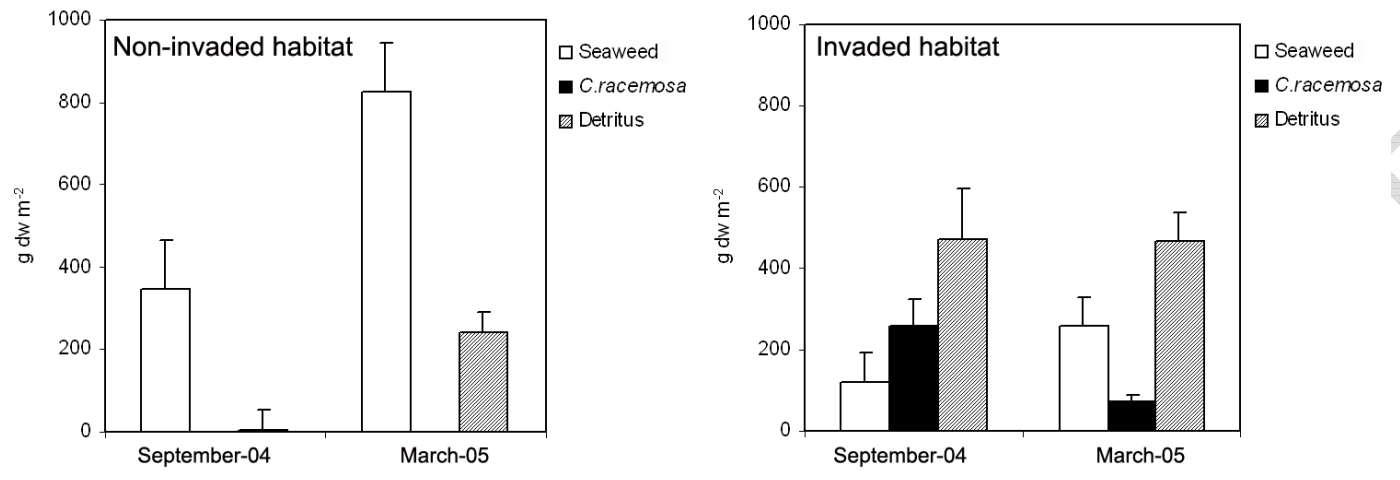

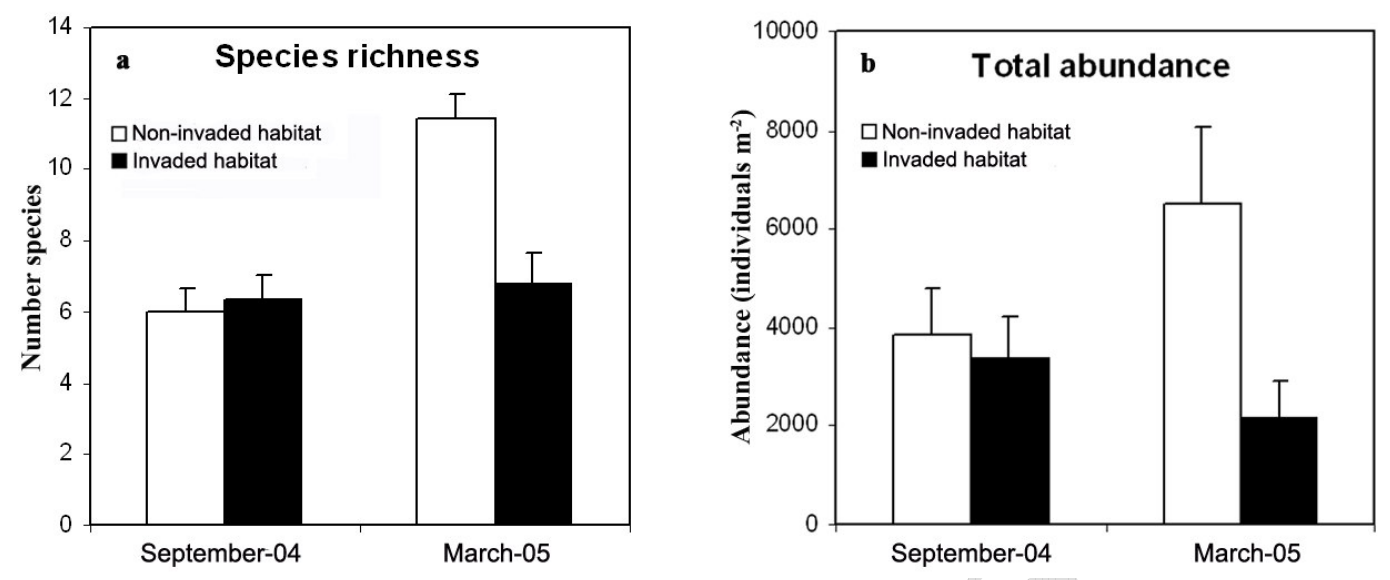


\section{ACCEPTED MANUSCRIPT}

572

Figure 5

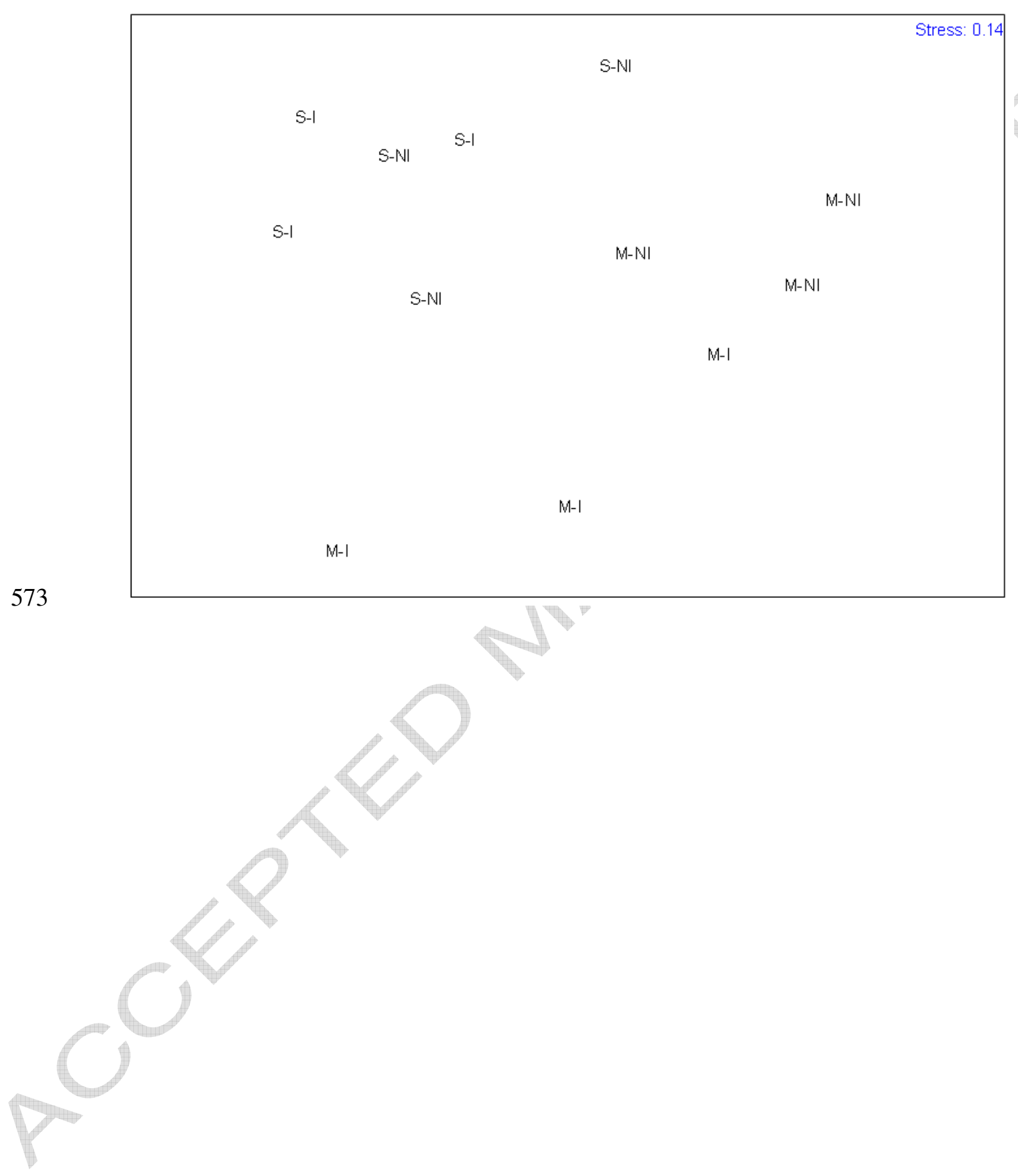


Figure 6
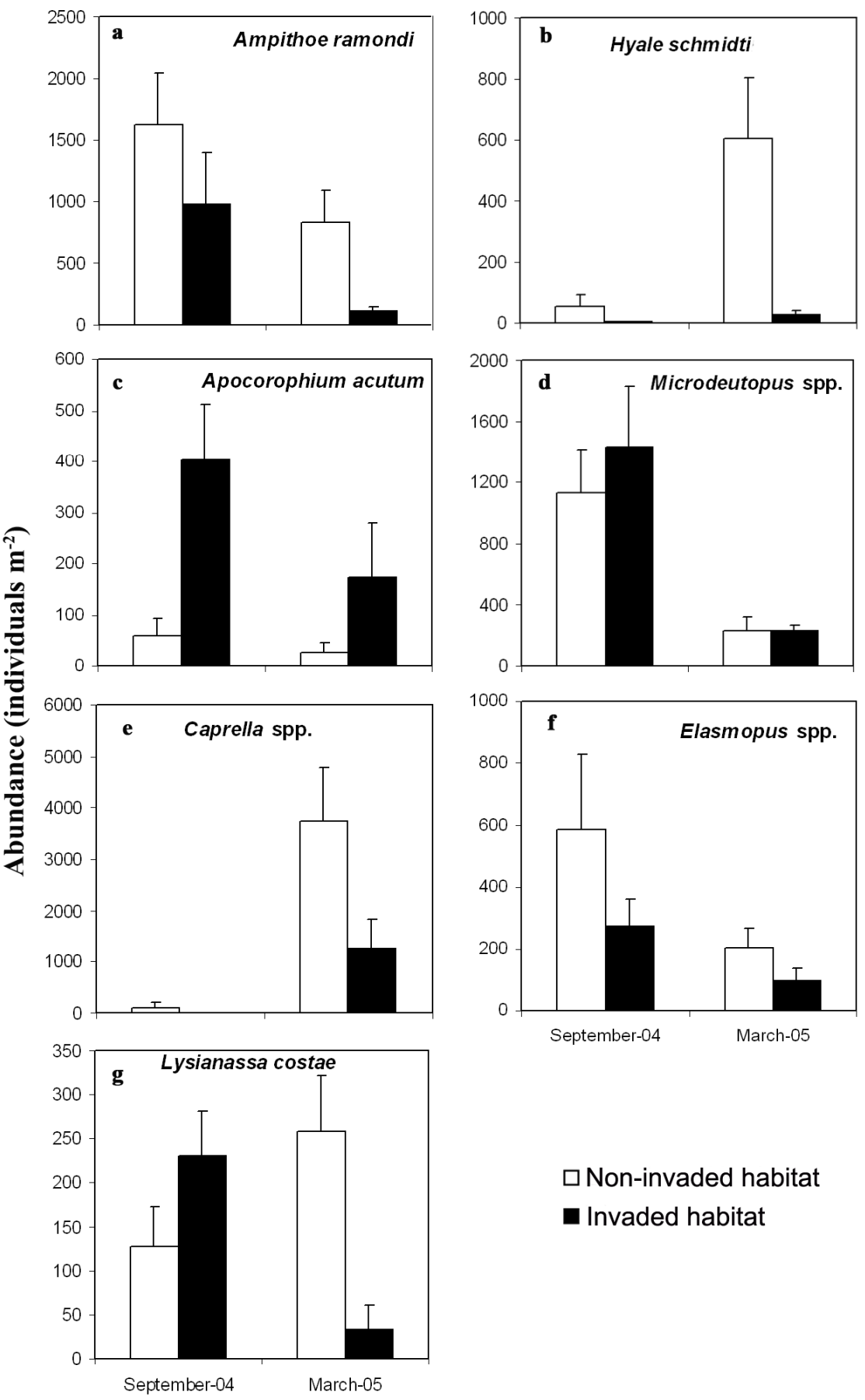

$\square$ Non-invaded habitat

- Invaded habitat 